\title{
I, Nadia, Wife of a Terrorist
}

\author{
Baya Gacemi (trs. Paul Cote and Constantina Mitchell) \\ Lincoln: University of Nebraska Press, 2006. 160 pages.
}

At the "Al Azhar" Association in Algiers, Algerian journalist Baya Gacemi recorded the story of a woman displaced by the country's surge of Islamist violence during the 1990s. Nadia, widowed, destitute, and alienated from her community, weaves her own story and those of other women against the backdrop of a wave of terror instigated by Islamist guerilla groups. Her story is perhaps the singularly most terrifying story of bastardized religiosity and a testament to the human spirit. Yet despite the hardships that Nadia narrates, she never asks for pity or sympathy; rather, she is wary of her pride, speaks candidly, and retains a dignity that makes her an extraordinary figure.

Unlike other testimonies from women in the Arab world, Nadia's story is different in that it is inclusive of her community and lacks the familiar formula of journalistic accounts from "stereotypically oppressive" Muslim nations. In her story, the optimistic details of her upbringing and first experience of love transition into the horror of the Islamic Action Group's (GIA) germination in the wilderness surrounding her village. She marries her first love, Ahmed, a local thug whose sole intention in life is to compensate for his decided lack of a masculine role model.

On the day of their marriage, Nadia engages in bridal rituals that include the use of cosmetics and henna, much to her husband's dismay. At this moment, we see a familiar Islamist tableaux unfold in the microcosm of the household, when Ahmed declares: 'From now on, you won't be going to the hammam anymore, or the hair dressers. And this is the last time I want to see you wearing makeup" (p. 32). Their marriage is not consummated on their wedding night, but rather spent engaged in extensive prayer and recitation of the Qur'an. Married for only a few hours, Ahmed disappears back to his spiritual brothers in the mountains. At this moment, Nadia begins to realize that Ahmed has not married her as a wife, but as a GIA (from French Groupe Islamique Armé) investment. Thus begins the cycle of her life as a wife of a GIA terrorist: She cooks meals, waits on her husband's fellow reprobates, and reaps the material and social benefits of the GIA's intimidation and thirst for blood.

Although Nadia could continue her story as a series of abuses and a testimony of her existence at the hands of a husband who abused her, she instead constructs the story of the GIA and its abuses as a central part of her 
account: She makes herself secondary, a simultaneously willing and unwilling participant in the GIA's brutal plans for a domestic genocide in order to return Algeria to a jahiliyah ruled by Muslims: "Next it'll be the journalists' turn. We have to get rid of them all, and all the intellectuals, too, because anyone who's educated can use the knowledge to fight us. After that, we'll kill everybody in key positions and all their relatives. It's the only way we'll be able impose the caliphate. Then we'll live the way they do in the soap operas on TV"' (p. 38).

Illogical as the GIA's plans are, the violence is very real and Ahmed's threats are especially bone-chilling. These threats come to fruition as Nadia details the various incidences that occur and are attributed to her husband, a GIA emir. Women are punished for not wearing the hijab outside of the house, five girls are beheaded for dressing provocatively, and even an old man is mauled when he is caught in the crossfire. As the violence peaks, so does the villagers' tolerance for intimidation and acquiescence to the GIA's demands. Under these circumstances, Nadia becomes a fugitive fleeing from a multi-pronged enemy.

Her husband's position forces Nadia, along with other women in similar positions, to seek out GIA safe houses where she can stay and be protected until the cloud of suspicion has passed. Summarily exiled from her own village, Nadia and other women are forced to create their own kind of Underground Railroad to work their way around the countryside surrounding Algiers. As the GIA's influence wanes, so does her ability to find safe houses. She is cast into the countryside, where her father regularly beats her, taking out not only his own but also a sense of national frustration with the Islamists. Finally, through the media that the GIA so despises and the murder of her husband, Nadia is able to liberate herself by means of Dalila Allal.

If one reads between the lines of this extraordinary testimony, one will not only recognize a familiar dynamic in the manner of how organic Islamism develops within nations like Algeria and Iraq, but also the profound resourcefulness of a nation and a people. The story is not only about Nadia's triumph in her suffering and acceptance of the guilt with which she is burdened, but also about the concept of redemption and healing. Her story fills in the gaps left by the meta-histories written by fellow Algerians like Assia Djebar. Her short biography is a gorgeous, heartbreaking testimony of violence perpetrated in the name of religion, as well as an account of the regeneration of society. Wise beyond her thirty years, she makes observations from which feminists and political scientists alike may draw inspiration. Her 
candor and redemption make her an exquisite star in a sky clouded by violence, suspicion, and sensationalism. Nadia is Algeria.

Alexandra Izabela Jérôme Professor of Islamic Studies York College of Pennsylvania, York, Pennsylvania 